of the subtropical region of South America (i.e., the transition between the tropics and the extra tropics) in deciphering the forcing factors of past changes in atmospheric circulation. Both Argentinean and Uruguayan Holocene paleolimnological records indicate similar paleoclimatic trends, i.e. dominant dry conditions were observed during cold phases, whereas wet conditions prevailed during warm climatic phases. To our knowledge, this is the first attempt to integrate paleoclimatic data for the whole Pampean region. In addition, our results underscore the need to reinforce paleoclimate research at mid-latitudes in South America, in an attempt to fully appreciate natural climate variability beyond the instrumental record, as well as to design new strategies for the sustainable development of ecosystems and natural resources.

\section{Acknowledgements}

PEDECIBA, SNI-ANII and CSIC-Program "Contratación de investigadores provenientes del exterior" (Uruguay) are thanked for financial support. Part of this study was supported by Argentina through funding of CONICET (PIP 5947; PIP 112-200801-00808), FONCYT (PICT No 25594 and PICT 2006-00625) and SECYT (UNC).

\section{References}

Bracco, R., Inda, H., del Puerto, L., Castiñeira, C, Sprechmann, P. and García-Rodríguez, F., 2005: Relationships between Holocene sea level variation, trophic development and climate change in Negra Lagoon, southern Uruguay, Journal of Paleolimnology, 33: $252-262$ del Puerto, L, García-Rodríguez, F., Inda H., Bracco, R., Castiñeira, C., J.B. and Adams, J.B., 2006: Paleolimnological evidence of Holocene paleoclimatic changes in Lake Blanca, southern Uruguay, Journal of Paleolimnology, 36: 151-163.

García-Rodríguez, F., 2006: Inferring paleosalinity changes using the chrysophyte cyst to diatom ratio in coastal shallow temperate/ subtropical lagoons influenced by sea level changes, Journal of Paleolimnology, 36, 165-173.

Piovano, E., Ariztegui, D., Bernasconi, S.M. and McKenzie, J.A., 2004 Stable isotopic record of hydrological changes in subtropical Laguna Mar Chiquita (Argentina) over the last 230 years, The Holocene, 14(4): 525-535.

Piovano, E.L., Ariztegui, D., Córdoba, F., Cioccale, M. and Sylvestre, F., 2009: Hydrological variability in South America below the Tropic of Capricorn (Pampas and Patagonia, Argentina) during the last 13.0 In: Vimeux, F. et al., (Eds.), Past climate variability in South America and Surrounding regions: From the Last Glacial Maximum to the Holocene, Developments in Paleoenvironmental Research Series (DPER), pp 323-351,

For full references please consult:

www.pages-igbp.org/products/newsletters/ref2009_3.html

\title{
Results of recent sediment drilling activities in deep
} \section{crater lakes}

\author{
Reinhard Pienitz' ${ }^{1}$, M. Melless and B. Zolitschka ${ }^{3}$ \\ 'Aquatic Paleoecology Laboratory, Centre for Northern Studies, Université Laval, Quebec City, Canada; reinhard.pienitz@cen.ulaval.ca \\ 2Institute of Geology and Mineralogy, University of Cologne, Germany; mmelles@uni-koeln.de \\ 3GEOPOLAR, Institute of Geography, University of Bremen, Germany; zoli@uni-bremen.de
}

\section{Long terrestrial sediment records from deep crater lakes reveal precious paleoclimate archives.}

Since the beginning of concerted efforts to extract long continental paleoclimate archives from lacustrine sediment records (see Leroy and Williams, 1996; Ariztegui, 1999), the terrestrial paleoclimate community has made substantial progress in providing precious paleoclimatic information from a number of sites in both hemispheres. Here we report on the latest achievements and progress made in three of these projects that concern large and deep crater lakes.

\section{Laguna Potrok Aike}

The Potrok Aike Maar Lake Sediment Archive Drilling Project (PASADO) is a deep lake drilling project sponsored by the International Continental Scientific Drilling Program (ICDP), as well as the German and Swiss National Science Foundations, Natural Sciences and Engineering Research Council of Canada, the Swedish Vetenskapsradet, and the University of Bremen (Haberzettl et al., 2007). Laguna Potrok Aike $\left(51^{\circ} 59.0^{\prime} \mathrm{S}, 70^{\circ} 21.0^{\prime} \mathrm{W}\right.$; $113 \mathrm{~m}$ asl, diameter 3.5 km, water depth 100 m; Fig. 1a) is a late Quaternary volcanic crater lake in southern Patagonia (Argentina). From September through November 2008, sediment cores were retrieved by an international team from all funding countries and the United States using the GLAD800 drill rig. A total of $513 \mathrm{~m}$ of sediments were recovered from two sites in seven holes and resulted in a composite sediment length of $107 \mathrm{~m}$, potentially representing a lacustrine archive of southern hemispheric environmental change of the past ca. 80 ka. Core sections and sediments are now stored and archived in the GEOPOLAR lake core repository at the University of Bremen. Various non-destructive analyses (multi-sensor core logger, digital photography and radiography, reflectance photospectrometry, magnetic susceptibility, XRF scanning) are almost complete while sub-sampling of the cores is underway for analyses of biotic and abiotic proxies (pollen, diatoms, chironomids, stable isotopes, rock- and paleomagnetics, geochemistry, grain size, mineralogy, pigments, organic petrology, microbial activity). Moreover, radiometric and luminescence dating techniques and tephrochronology will be applied to assure the best possible time control. The analysis of this unique Southern Hemisphere sediment record will provide insights into lacustrine ecosystem response to climate forcing since the onset of the last glacial, and will allow correlation of this record with marine and Antarctic counterparts to detect landocean-cryosphere-atmosphere interactions. Information on the latest progress of this research project can be found at http://www.pasado.uni-bremen.de or http://www.icdp-online.org/contenido/ icdp/front_content.php?idcat $=722$, or by contacting Bernd Zolitschka.

\section{Pingualuit Crater Lake}

Pingualuit Crater Lake $\left(61^{\circ} 17^{\prime} \mathrm{N}, 73^{\circ} 41^{\prime} \mathrm{W}\right.$; $520 \mathrm{~m}$ asl, diameter $3.4 \mathrm{~km}$, cover photo) resulted from a meteoritic impact that occurred ca. 1.4 million years ago. Due to its unique bowl-shaped morphometry (270 $m$ deep, almost perfectly circular), the lake bottom should have escaped glacial erosion. Based on a single punctual seismic survey, the uppermost $8.5 \mathrm{~m}$ of sediments were recovered (overall length of all sediment sections $=11.2 \mathrm{~m}$ ) through the ice at a water depth of $260 \mathrm{~m}$ by an international team in early May 2007 (Fig. 1b). High-resolution physical (CAT-Scan, Multi Sensor Core Logger, diffuse spectral reflectance), geochemical (ITRAX core scanner, carbon and nitrogen contents, $\delta^{13} \mathrm{C}$ of the organic matter), and magnetic (magnetic susceptibility, natural, anhysteretic, isothermal and saturation isothermal remanent magnetizations) analyses were performed. Two main lithofacies were clearly identified by the different measurements, which likely represent successive interglacial-glacial cycles. Most of the sediment consists of light grey silts containing several angular rock fragments, characterized by very low organic carbon content, relatively high density and magnetic susceptibility, and therefore suggesting deposition during 


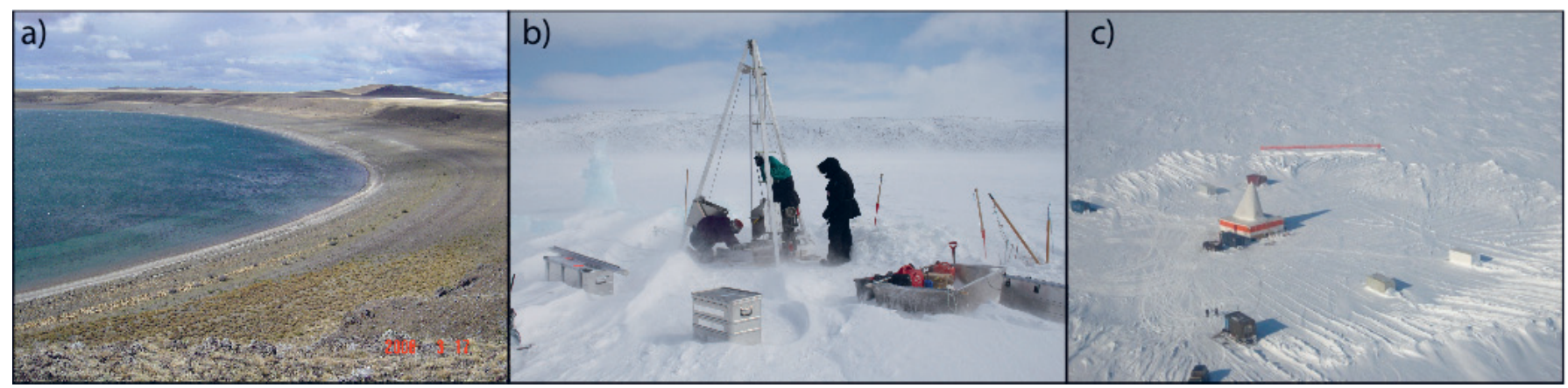

Figure 1: a) Laguna Potrok Aike in southern Patagonia (Argentina) (photo: Reinhard Pienitz, Université Laval); b) Coring of Pingualuit Crater Lake sediments in early May 2007 (photo: Veli-Pekka Salonen, University of Helsinki); c) Aerial view of the drilling platform on Lake El'gygytgyn in April 2009 (photo: Kristina Brady, LacCore, Minneapolis).

glacial conditions. Interbedded between this facies are at least two, decimeterthick, organic-rich and finely laminated intervals likely representing ice-free periods. This is supported by the presence of fossil pollen, diatoms, chrysophytes, and chironomid head capsules, as well as high biogenic silica content (up to $20 \%$ ) in sediments from these two intervals. In addition, preliminary Infrared Stimulated Luminescence (IRSL) dating indicates that the upper organic-rich layer has an age coeval with the last interglacial (Marine Isotope Stage 5, MIS 5), while the age of the lower organic-rich layer is consistent with an older interglacial, likely MIS 7. The sedimentary infill thus constitutes a unique long-term record of past environmental conditions for the Canadian and North American Arctic that will allow for comparisons with land-based, ocean and ice core records from the northern circumpolar region. Furthermore, the presence of a subglacial lake during the last two glacial periods can be inferred because the sediments escaped glacial erosion. Microstratigraphical analyses of thin sections are currently underway to define the depositional environments of each laminated interval. The Pingualuit Crater Lake drilling project is sponsored by the Canadian Foundation for Climate and Atmospheric Sciences. To be informed about the latest progress made within this research project, please refer to the websites (http:// www.cen.ulaval.ca/pingualuit/index.html or http://www.cen.ulaval.ca/paleo/index. html) or contact Reinhard Pienitz.

\section{El'gygytgyn Crater Lake}

Lake El'gygytgyn is a $3.6 \mathrm{Ma}$ old impact crater in northeastern Siberia $\left(67^{\circ} 30^{\prime} \mathrm{N}\right.$, $172^{\circ} 05^{\prime} \mathrm{E} ; 492 \mathrm{~m}$ asl). The lake has a roughly circular shape with a diameter of $12 \mathrm{~km}$ and a bowl-shaped bathymetry with a maximum water depth of $170 \mathrm{~m}$. In May 2009, a six-month drilling operation in the El'gygytgyn Crater was completed by an international team from Russia, Germany, the United States, and Austria. Drilling was carried out from the ice, which had to be artificially strengthened to support the 75-ton drilling platform (Fig. 1c). This "Russian GLAD 800" was developed and operated by DOSECC and was permanently imported into Russia, where it will be available at no cost for the next five years for scientific drilling projects financed by the major funding agencies of the El'gygytgyn Drilling Project: ICDP, the US National Science Foundation, and the German Federal Ministry for Education and Research, with additional financial contributions by the Russian Academy of Sciences and the Austrian Federal Ministry of Science and Research. The project completed three holes in the center of Lake El'gygytgyn, reaching a maximum depth of $517 \mathrm{~m}$ below lake bottom. The upper $312 \mathrm{~m}$ of the crater fill consist of lake sediments. Extrapolating the sedimentation rates known for the last $300 \mathrm{kyr}$ from cores recovered during site surveys, this lacustrine sequence likely represents the entire history since the impact event 3.6 Ma ago. This record opens new opportunities to investigate the natural environmental change from the Pliocene terrestrial Arctic, when global climate was significantly warmer than today, via the glacial-interglacial cycles since the Pliocene/Pleistocene transition 2.6 Mio years ago, to more short-term, millennial- to centennial-scale climate events. Comparison of the results with ocean and land-based records from lower latitudes will significantly enhance our understanding of the role of the Arctic in the global climate system. Underneath the lake sediments, a suevite layer of ca. $60 \mathrm{~m}$ thickness, containing impact glasses from melted target rocks, was penetrated, before more than $140 \mathrm{~m}$ of broken and fractured basement rocks were drilled, which had become shocked, brecciated, and uplifted during the impact event. Detailed investigations of the impact rocks will provide new information on the composition and nature of the meteorite that formed the crater and on the energy released during the impact. Of special interest are the acidic volcanic rocks, which form the target rocks of the El'gygytgyn impact.
Their investigation will enhance our understanding of the impact and shock effects on such rocks, which has implications for comparative planetology. In addition to lake drilling, a $142 \mathrm{~m}$ drill core was retrieved from the permafrost deposits at the western shore of Lake El'gygytgyn. The core contains coarse-grained, ice-rich alluvial fan and near-shore lake deposits. Their investigation will provide information on the permafrost history and lakelevel changes, both of which may have influenced the sedimentation in the lake center. After drilling, the permafrost borehole was permanently instrumented with a thermistor chain for future ground temperature monitoring as part of the Global Terrestrial Network for Permafrost (http:// www.gtnp.org/index_e.html). For more detailed information on the drilling project see the websites http://www.elgygytgyn.uni-koeln.de, http://www.geo.umass. edu/lake_e, and http://www.icdp-online. org, or contact Martin Melles.

\section{Conclusion}

The long continental sediment cores recovered and the initial results obtained so far from these three crater lakes indicate that their paleoclimate records will provide new insights into the linkages between climate forcing processes and global paleoenvironmental changes, thereby improving the output of regional to global climate models. More lake drilling projects of this kind are presently underway or in the planning stage, which will make a significant contribution to a better understanding of past, present, and future climate dynamics.

\section{References}

Ariztegui, D., 1999: Large Lake Records and New Perspectives for Continental Paleoclimate Archives, PAGES news, 7(1): 12.

Haberzettl, T., Mayr, C., Wille, M. and Zolitschka, B., 2007: Linkages between southern hemisphere westerlies and hydrological changes in semi-arid Patagonia during the last 16,000 years, PAGES news, 15(2): 22-23.

Leroy, S.G. and Williams, D.F., 1996: Continental Drilling for Paleoclimate Records, PAGES news, 4(1): 3 